\title{
The Effect of Retaining Bonuses on Delaying Early Retirement - Financial Incentives Revisited'
}

I Åsmund Hermansen ${ }^{2}$

Associate Professor, PhD, OsloMet - Oslo Metropolitan University, Norway

I Tove Midtsundstad

Researcher Professor, PhD, Fafo, Institute for Labour and Social Research, Norway

\begin{abstract}
In this paper, we analyze the effect of the retaining bonus on early retirement behavior using a unique dataset consisting of a Nonwegian employer survey from 2010 combined with register data on all older employees in the period 2000-2010. The retaining bonus is one of the most common retention measures offered by Nonwegian companies to prevent their older workers from retiring early. The most common arrangement is a lump sum of between 10,000 and 25,000 Norwegian Kroner (between 1100 and 2600 Euros), which was less than the mean monthly pay before tax in Norway in 2010 . In spite of this modest sum, our analysis shows that retaining bonuses of 20,000 NOK or more do reduce the probability of 61 -year-olds retiring in the next two years of employment.
\end{abstract}

\section{KEYWORDS}

Early retirement / financial incentives / older workers / retention measures

\section{INTRODUCTION}

D educing early retirement is a goal that features on social policy agendas across Europe, and as people are 'living longer', keeping them 'working longer' is at the core of the social policy debate (OECD, 2006; Phillipson, 2013). In Norway, as in many other European countries, the makers of social policy are acknowledging the fact that a significant change in retirement behavior will come from the modification of employers' policies and retention efforts (Vickerstaff et al., 2003). Employers play a key role in defining the opportunities for working longer, thus the success of policy aimed at delaying retirement depends to a significant degree on the actions and attitudes of employers (Henkens \& van Dalen, 2012). In spite of the increased awareness of the role played by employers, research on the efficacy of retention measures at the company level is limited (Hilsen \& Midtsundstad, 2015).

In Norway, one of the most common retention measures used by employers to prevent their older workers from making an early exit is the retaining bonus. In 2010, more than $10 \%$ of Norwegian companies (with 10 or more employees) offered their older workers such monetary rewards if they continued working past the age of 62 (Midtsundstad \&

\footnotetext{
${ }^{1}$ You can find this text and its DOI at https://tidsskrift.dk/njwls/index.

${ }^{2}$ Email: asmund.hermansen@hioa.no.
} 
Bogen, 2011). The most common arrangement was a lump sum of between 10,000 and 25,000 Norwegian Kroner (between 1000 and 2600 Euros), which was less than the mean monthly pay before tax in Norway in $2010^{1}$. Given the relatively low sum offered, it is doubtful whether such retaining bonuses can be effective in altering early retirement behavior. In addition, research shows that the retirement planning of older male workers is more affected by an increase in earnings than the retirement planning of older female workers is, suggesting that employer-initiated measures will not necessarily be as effective in retaining female workers (Larsen, 2008). Thus, the aim of this paper is to investigate whether being offered a retaining bonus has an effect on the probability of opting for early retirement, and whether the effect differs by gender.

There is a substantial strand of research investigating the effect of pension benefits and tax rates on early retirement behavior, and most of these studies show that financial incentives have an impact on retirement behavior (Bratsberg et al., 2008; Gruber \& Wise, 2010). Nevertheless, they also show that the financial reward must be of a significant size to alter retirement behavior (Hernæs, 1999; Krueger \& Pischke, 1992). However, these studies investigate the effect of 'passive' policies at the national level and not 'active' measures at the company level (Corsi \& Samek, 2010). Thus, this paper addresses a gap in the research literature by investigating the effect of an 'active' measure used by employers to retain their older workers. Furthermore, we investigate whether the effect of retaining bonuses varies according to gender and income group. Our analysis is based on a unique dataset consisting of a Norwegian employer survey from 2010 combined with register data on all older employees in the period 2000-2010.

\section{POLICY CONTEXT}

\section{Active aging in Norway and the retaining bonus}

Like many European countries, Norway has adopted a twofold active-aging strategy consisting of 'passive' labor market policies and 'active' measures aimed at retaining older workers (Corsi \& Samek, 2010). The pension reform, implemented from January 1, 2011, represents the 'passive' part of Norway's strategy, and early retirement is discouraged through introducing actuarial neutrality, by tightening the link between contributions paid and benefits received by the individual, and by calculating benefits according to life expectancy.

The second part of the Norwegian strategy, emphasizing the use of 'active' measures, was formulated in 2001 at the national level with the signing of the Tripartite Agreement on an Inclusive Working Life (the IWL agreement). With the introduction of the IWL agreement, the Norwegian government and the social partners called for employers to assume greater social responsibility for keeping people in employment and preventing older workers from making an early exit (Midtsundstad, 2011). Since the introduction of the IWL agreement, the use of retention measures at the company level has increased significantly. The two most common retention measures in Norway in 2010 were additional leave and phased retirement, making the retaining bonus the third most used 'active' measure aimed at extending the working lives of older workers (Hermansen \& Midtsundstad, 2015).

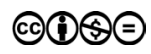


The retaining bonus is a monetary reward offered from a given age to all employees working in companies with such a measure, in addition to their fixed compensation. Thus, the only criteria for being offered such a bonus is that employees continue working after a certain age; all employees who pass this age threshold are given the bonus. The most common age for being entitled to a retaining bonus was 62 years $^{2}$ in 2010, which is the eligible age for withdrawing early retirement benefits (AFP) in Norway. The most common level of compensation ${ }^{3}$ was between 10,000 and 25,000 Norwegian Kroner (between 1100 and 2600 Euros), significantly less than 36,700 Norwegian Kroner (about 3800 Euros), the mean monthly pay before tax in 2010 .

The number of companies offering a retaining bonus was quite low prior to 2005, with fewer than $2 \%$ of companies using this retention measure. However, bonuses gained greater popularity from 2005; in 2006, $4 \%$ of Norwegian companies with 10 or more employees offered a retaining bonus, and by 2010 , a total of $10 \%$ offered this measure (Midtsundstad \& Bogen, 2011). The fact that a relatively small number of Norwegian companies offer a retaining bonus can be explained by the fact that Norwegian companies operate within a framework, which offers few incentives for retaining older workers. The main exception was the contractual pension (AFP), which meant that (until 2011 in the private sector) employers shouldered an extensive share of the cost if one of their employees chose to retire between the ages of 62 and 67. A study by Hermansen and Midtsundstad (2015) also shows that offering retaining bonuses was much more common among companies with a contractual early retirement scheme in 2010 . Thus, they conclude that the financial incentives embedded in the contractual pension seem to be of significant importance for the retention efforts of Norwegian companies. However, the study shows that offering a retaining bonus is not correlated with number of employees, whether the company has signed the IWL agreement or not, perceived labor shortages, the time required to train new staff, or the proportion of older workers in the company (Hermansen $\&$ Midtsundstad, 2015).

\section{The labor market in Norway and the contractual pension}

The overall labor market situation does undoubtedly affect the employment situation for older workers, and it must be underscored that Norway, since the beginning of the new millennium, has enjoyed a period of strong economic expansion. Even during periods of economic downturn for the rest of Europe and strong increases in unemployment rates, the expected remaining years in employment for a 50-year-old in Norway has been steady or rising. Figures from the National Labor and Welfare Administration (NAV) show a strong increase in the expected remaining years in employment for a 50-year-old in the period 2001-2014. In 2001, the expected remaining years in employment for a 50 -year-old was on average 9.6 years, whereas in 2010, it was 10.9, increasing further still to 11.5 in 2014 (Haga, 2015). Accordingly, Norway has one of the highest employment rates among 55- to 64-year-olds in Europe and an employment rate above the OECD average (OECD, 2013). Furthermore, the Norwegian 'age-culture' is, according to de Vroom (2004), the 'extreme' case in Europe, in the sense of being work-oriented; it is based upon a broadly accepted and institutionalized norm that older workers have a right and a duty to participate in the labor market. Thus, both a favorable economic 
situation and work-oriented culture have contributed to an overall high employment rate among older workers.

The high employment rate among older employees in Norway can also partly be explained by the following five factors (Midtsundstad, 2011). First, compared with other European countries, the employment rate among women has been high for many years. Second, until 2011, Norway had a relatively high statutory retirement age, 67 years for both men and women. Third, the possibility of retiring at the age of 62 was first given to Norwegian employees in 1998 through the contractual pension (contractual early retirement pension or AFP scheme). Fourth, from 1997, the contractual pension allowed individuals to combine part-time work with a partial contractual pension, provided that it was approved by their employer, thus making it easier for many older workers to continue working. Fifth, Norwegian employers cannot terminate the employment contract before employees turn 70 (today 72), with some exceptions ${ }^{4}$ (the Work Environment Act $\$ 15-13)$. In addition, redundancy regulations in Norway normally follow the 'last in, first out' principle, making dismissal protection in Norway especially strong for older workers with seniority (Svalund et al., 2015).

The contractual pension or contractual early retirement scheme (AFP scheme) offers older workers the possibility of opting for early retirement between the ages of 62 and 66 years of age. From January 1, 2011, the contractual pension was changed to a flexible lifelong annuity for private sector workers, making the scheme distinctly different from the public sector where it is still designed as an early retirement scheme. Nevertheless, this regulatory change was implemented after the timespan investigated in this article. Early retirement was available to all public sector workers and about $40 \%$ of private sector workers (only private sector employees working in companies covered by a collective agreement have an AFP scheme) (Nergaard, 2009). On average, about $40 \%$ of those still working at age 61 in the private sector retried on the AFP scheme in the next two years of employment during the period 2006-2010 (LO \& NHO, 2017).

\section{THEORETICAL FRAMEWORK}

\section{The retirement puzzle}

The early retirement puzzle is complex and being offered a retaining bonus is just one of many factors in the work-retirement transition (Wang \& Shultz, 2010). As expressed by Philipson (2013:148): 'The complexity of the transition from work to retirement stems from being at the heart of the "messy" reality of people's lives, cutting across individual and household characteristics, work contexts, and wider economic and sociological forces'. Thus, understanding the retirement transition and the possible role played by retaining bonuses in keeping older workers in employment rests on our ability to recognize the variety of factors influencing early retirement practices. In an effort to explain this complexity, theoretical traditions within the research literature on early retirement behavior present different factors influencing labor supply in the final phase of working life. The different perceptions of factors used to explain early retirement primarily stem from differences in the notion of whether the exit is voluntary or involuntary and whether it is mainly affected by labor supply or labor demand (Engelhardt, 2012; Jensen \& Øverbye, 2013; Midtsundstad, 2012).

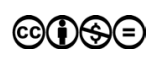




\section{The economic theory of retirement}

Working on the assumptions that preferences are homogeneous and individuals only work to maximize their lifetime earnings, the economic theory of retirement models the retirement decision as a strictly financial calculation with consumption as the final aim (Engelhardt, 2012; Radl, 2012). Desiring leisure over work, utility-maximizing workers select the time they believe is optimal to retire, taking into consideration financial opportunities and constraints. Thus, the financial incentives embedded in early retirement pension schemes and other welfare-state programs 'pull' older workers out of working life (Gruber \& Wise, 2010; Hernæs et al., 2002). The opportunities for different action alternatives are determined by the accessibility and performance of the various pension schemes available, which are decisive when making the choice between work and leisure. Payment levels and corresponding tax rates, age restrictions, and selection criteria act as factors 'pulling' employees out of working life early. Hence, the labor market exit of older workers can be traced back to the financial incentives to retire offered by early retirement pension schemes and other welfare-state programs (Engelhardt, 2012; Gambetta, 1987; Gruber \& Wise, 2010).

\section{Critic of the economic theory of retirement}

The economic theory of retirement has long been criticized for modeling the transition between employment and retirement as a voluntary choice (Engelhardt, 2012). The approach neglects the labor demand side, focusing exclusively on the individual decision and hence taking a singular labor-supply view. As a modification to the fundamental economic principle that 'if they aren't paid, people don't work' (Gruber \& Wise, 2002: 1), sociological approaches to early retirement usually assume that there is an intrinsic value to work. People do not see work as merely a source of income, but also as a way of gaining self-realization, social recognition, and social contacts (Doherty, 2009; Radl, 2012; Riach \& Loretto, 2009). Radl (2012) emphasizes that the intrinsic value of work should be reflected in a resistance to leave work prematurely, a hypothesis which is supported by the frequent occurrence of older workers being 'pushed' out of work or into involuntary retirement (Calvo et al., 2013; Halvorsen, 1977).

Evidence indicates that intrinsic factors, such as the meaningfulness of work, autonomy, and work enjoyment, may have an even greater influence on retirement decisions than extrinsic factors, such as financial incentives (Waginger, 2015). Adding to this research, a large meta-analysis conducted by Kooij et al. (2011) shows a significant positive correlation between intrinsic motivators and age and a negative correlation between extrinsic factors and age.

\section{A social and cultural understanding}

Beyond relating 'pull factors' to purely financial incentives and a preference for leisure over work, sociological research has also added a more social and cultural understanding of these factors. From a sociological point of view, early retirement schemes reproduce the culturally constructed notion of when older workers should leave the labor 
market (Jensen \& Øverbye, 2013). Hence, early retirement schemes underpin an 'early exit' regime by influencing when older workers believe they are supposed to retire, exerting an independent normative effect, 'pulling' older workers out of work early (Esser, 2005; Jensen \& Øverbye, 2013). The existence of internalized age norms concerning retirement timing is documented in empirical studies across European countries (Esser, 2005; Radl, 2012). Such age norms can also 'push' older workers out of the workforce early, in the sense that culturally constructed age norms make older employees leave the labor market early due to social pressure, and not a desire to retire early (Radl, 2012).

In contrast to the economic research emphasizing free and unconstrained individual choice, a significant part of the research literature on early retirement has focused on involuntary retirement as a result of 'push factors'. This includes labor market and company-level push factors such as structural adjustments, rationalization, increased eligibility requirements, and other factors that 'push' elderly, less productive, or less skilled labor out of the labor market (Midtsundstad 2005; Halvorsen, 1977). Referred to as 'individual push factors', health problems, as well as physical and mental strains related to the job, have proven to increase the likelihood of older workers opting for early retirement (Calvo et al., 2013; Engelhardt, 2012; Gørtz, 2012; Midtsundstad 2005; Larsen, 2004).

\section{The retaining bonus}

As a retention measure, the retaining bonus will mainly reduce the significance of economic 'pull factors' in the transition between work and retirement, as it changes the compensation rate, making work more economically valuable than leisure. However, offering a retaining bonus might also send a signal to older workers that they are wanted and appreciated. Such signals may help to reduce the significance of the culturally constructed beliefs about when older workers should leave the labor market and thus the effect of culturally constructed 'pull' or 'push' factors. This 'signal effect' may be as important as the financial effect when older workers are weighing the pros and cons of continuing working versus leaving the labor market altogether. Analyses explaining the factors of early retirement practices that emphasize only 'pull' or 'push' factors have proven to be inadequate (Engelhardt, 2012; Midtsundstad 2005). Both sets of factors are relevant, as there may be a variety of factors influencing early retirement behavior. Thus, analyses of early retirement behavior benefit from including a model that sufficiently recognizes the variety of factors influencing early retirement practices and as comprehensively as possible controls for the complexity of these factors.

\section{PREVIOUS RESEARCH}

\section{Previous studies of retaining measures}

According to a newly published international literature review (Hilsen \& Midtsundstad, 2015), few policies and facilitation programs for older workers have been evaluated and only a few studies have investigated the effects of retention measures on early retirement behavior in Norway. Evaluating the overall effect of being offered retention measures 
using a difference-in-differences approach, Midtsundstad et al. (2012) found that these measures did not help to delay retirement among older workers in Norway in the period 2005 to 2007 . A study by Hermansen (2015) also shows that being offered the possibility of phased retirement does not reduce the likelihood of 61- and 62-year-olds retiring in the next two years of their employment. Meanwhile, another study on the effect of additional leave as a retention measure shows that being offered extra days off reduces the likelihood of retiring early (Hermansen, 2014). To the extent of our knowledge, no studies have investigated the effect of retaining bonuses offered by companies to alter early retirement behavior, thus the analysis in this paper is the first of its kind.

\section{Financial incentives - buy-outs, job-performance, and 'Early Retirement Windows'}

In the international literature, the use of financial incentives, such as bonuses, is often studied in connection with special early retirement programs, referred to as buy-outs, aimed at encouraging older workers to opt for early retirement. Using a Swedish register-based longitudinal dataset, Hallberg and Eklöf (2010) investigate the effect of buyouts on early retirement behavior. The results indicate that the probability of making an early exit from working life decreases in the absence of buy-outs, the decrease being somewhat larger among men than among women.

In a US study based on the Health and Retirement Study (HRS), Brown (2002) studied the prevalence and effect of so-called 'Early Retirement Windows' or 'Early-out Windows', defined as special financial incentives to retire at a particular time (Brown, 2002). Using a sample of workers between the ages of 51 and 61 from the HRS in 1992, Brown found that those who received window offers were less likely to work in the subsequent wave of the HRS, the effect being largest at the interview following the window offer, declining rapidly thereafter (Brown, 2002).

\section{The work-continuation bonus, pension benefits, and tax-rates}

Using data from a Dutch longitudinal household panel (the LISS panel) for the period 2008-2012, da Silva Soca (2013) investigated the effect of a so-called work-continuation bonus (doorwerkbonus) on retirement behavior among older Dutch workers. The doorwerkbonus was introduced by the Dutch government in 2009, seeking to delay retirement by providing a discount on taxable income from 62 years of age. Applying a difference-in-differences approach, da Silva Soca concludes that the reform led to an increase in the expected ${ }^{5}$ retirement age for those workers who were eligible to the doorwerkbonus. However, the study does not shed light on whether the work-continuation bonus affected the actual retirement age.

Larsen (2008) investigates whether a number of quality of work life measures differ in importance for male and female workers in their retirement planning, using data from a Danish survey merged with longitudinal register data. The results suggest that male and female workers are affected differently by various aspects of the job. A substantial strand of reseach has also investigated the effect of different sorts of pension benefits and tax rates on the retirement behavior of older workers. Most of these studies show 
that financial incentives have an impact on retirement behavior (Bratsberg et al., 2008; Gruber \& Wise, 2010). The effect seems to be stronger for those in lower, than for those in higher income groups. Nevertheless, they also show that the financial reward must be of a significant size to alter retirement behavior (Hernæs, 1999; Krueger \& Pischke, 1992). However, as previously highlighted, these studies investigate the effects of 'passive' policies at the national level and not 'active' measures at the company level, such as the retaining bonus.

\section{Quality of work, intrinsic, and extrinsic factors}

Larsen also found that the retirement plans of both men and women were affected by an increase in earnings, however, significantly more so for men than for women. A $10 \%$ increase in income increased the planned retirement age by half a month among women and by four months among men. Such a permanent wage increase is substantially higher than the retaining bonuses investigated in this article, and is as such not a retaining bonus.

Even though the retaining bonus essentially is just a financial incentive, case studies show that many older works view such a bonus as a signal that they are wanted and appreciated (Midtsundstad \& Bogen, 2011). Hence, a bonus offered as part of a company's active aging policy is more than a simple wage increase. Furthermore, studies shows that the feeling of being wanted and appreciated by the company is in itself important for employee's decision to continuing working beyond retirement age (Jensen, 2011; Midtsundstad \& Bogen, 2011).

\section{METHODS}

\section{Data}

The data used in this paper covers the period 2000-2010 and comprises all 61-year-old employees ( $N=12513$ ) who were employed in one of 437 (from a total sample of 800) companies that participated in a 2010 survey. All information on the individual employees working in these companies has been provided by Statistics Norway (SSB) and is drawn from administrative registers.

The sample of 800 companies was representative for all Norwegian companies with 10 or more employees in 2010 (see Midtsundstad \& Bogen, 2011, for an extended documentation of the survey). The survey was conducted in the period August to September 2010 by Respons Analyse AS, a Norwegian research firm, on behalf of the Fafo Institute for Labor and Social Research. The survey provides information on company characteristics, and whether a retaining bonus is used as a retention measure, and, if so, in which year the retaining bonus was introduced and the amount offered (Midtsundstad \& Bogen, 2011).

The survey had a response rate of $50 \%$. In the sample, there was an underrepresentation of small companies (10-19 employees) and companies in wholesale and retail trade industry, and an overrepresentation of large companies (250 or more employees) and public sector companies. In this analysis, however, we only use data from employees 
working in companies with a contractual pension (AFP scheme), which included all public sector companies, but only half of the private sector companies (of which few are small companies and/or within the wholesale and retail trade industry). Furthermore, we have only included companies with one or more employee aged 61. This criterion was chosen because only employees in companies with an AFP-scheme had the opportunity to voluntarily draw an old-age pension at age 62 before the pension reform in 2011 . Of the 800 companies that participated in the 2010 survey, 437 companies met these two criteria - 129 in the public sector and 308 in the private sector.

\section{Dependent and explanatory variable}

The dependent variable is measured as withdrawal of a contractual pension in the next two years of employment, among workers still working at age 61 in the period 2000-2008. Thus, the dependent variable is measured in the period 2001-2010. Employees aged 61 and withdrawing early retirement benefits in the next two years of employment are given the value ' 1 ' upon withdrawal, whereas those who do not retire are given the value ' 0 ' on the dependent variable.

The retaining bonus is measured as a dummy variable; those who are not offered a bonus are given the value ' 0 ', whereas those 61-year-olds who are offered the bonus are given the value ' 1 ' when they turn 62 . Thus, for those who are not offered a retaining bonus, the dummy variable is ' 0 ' at the ages of 61,62 , and 63 , whereas for those who are offered a bonus, the variable is ' 0 ' at age 61 and ' 1 ' at ages 62 and 63 .

\section{Model - Individual fixed effects}

In order to investigate the effect of the retaining bonus on early retirement behavior, we use the panel data method, individual fixed effects in combination with a linear probability model. The advantage of using individual fixed effects is that this model controls for all time-independent unobservable heterogeneity that could be correlated with the main independent variable and thereby produces an over- or underestimated coefficient. An individual fixed-effects model uses only variation within the same unit (individual) over time and therefore produces robust estimates on the effects of changes in different independent variables on different outcomes, controlling for all time-invariant explanatory variables and time-independent unobservable heterogeneity (Angrist \& Pischke, 2008; Wooldridge, 2005, 2009). Estimating the effect of the retaining bonus using individual fixed effects and a linear probability model can be written as follows (Angrist \& Pischke, 2008):

$$
\begin{gathered}
\mathrm{y}_{\mathrm{it}}=\alpha_{i}+\lambda_{i}+\beta x_{i t}+\beta 2 \operatorname{TREAT}_{i t}+\beta 3 A G E 62_{i}+\beta 4 A G E 63_{i}+\varepsilon_{i t} \\
\text { where, } i=1 \ldots \mathrm{n}, t=1, \ldots, T_{i}
\end{gathered}
$$

In the analysis, we investigate whether 61-year-olds working in companies offering a retaining bonus at age $62\left(\beta 2 B O N U S_{i t}\right)$ have a lower probability of retiring early $\left(\mathrm{y}_{\mathrm{it}}\right)$ in the next two years of employment. $\beta 2 B O N U S_{i t}$ equals ' 1 ' if the individual is offered 
a bonus at age 62 , and is still ' 1 ' for these individuals at age 63 . $\beta 3 A G E 62$ provides an estimate of the overall probability of retiring at age 62 for all included individuals and $\beta 4 A G E 63_{i}$ provides an estimate of the overall probability of retiring at age 63 . $^{2}$

A company is identified as offering a retaining bonus on the basis of the HR manager/executive director of the company in August-September of 2010 having reported to have made this measure available to older workers with the purpose of encouraging them to continue working. Among the companies having introduced a retaining bonus, only those with an entitlement age set at 62 years are included in the analysis. Offering a retaining bonus is a choice made by each individual company and hence the group of Norwegian companies offering this retention measure is self-selected. However, the distribution of older workers in the intervention group and the control group can be assumed to be random, given that very few employees change jobs after the age of 60 , enabling them to actively seek out companies with such retention measures for older workers (Lien, 2013; OECD, 2013). Furthermore, any time-invariant differences between workers being offered the retaining bonus and those not receiving such an offer is controlled for when using individual fixed effects. In addition to controlling for any time-invariant differences, we include time-variant controls in our analysis, guided by previous research.

\section{Control variables}

As previously mentioned, the advantage of using individual fixed effects is that these models control for all time-invariant explanatory variables and time-independent unobservable heterogeneity (Angrist \& Pischke, 2008; Wooldridge, 2005, 2009). Thus, despite not being listed in the tables reporting the results, we control for all time-invariant risk factors. Given that these factors are fixed and do not vary within the individual over time, the individual fixed-effects model does not estimate a covariate showing their effect on the outcome of interest (Angrist \& Pischke 2008; Wooldridge, 2005, 2009).

To account for the effect of time-varying financial incentives that might influence employees' probability of drawing an early retirement pension, 'income percentile' (net income after tax divided into percentiles); 'spouse income percentile' (spouse income after tax divided into percentiles) and 'household debts percentile' (household debts divided into percentiles) are included in the analysis.

Research on the relationship between marital status and economic activity shows that many couples 'coordinate' their retirement. The tendency for couples to make a joint exit from working life is known as 'the joint retirement hypothesis' (Lancee \& Radl, 2012). To control for the possibility that couples 'coordinate' their retirement, the analysis includes 'spouse retired on the contractual pension' and 'spouse retired on disability pension'.

We present descriptive statistics for the control variables and a selection of key information for the group of 61-year-olds being offered a retaining bonus and the 61-year-olds not being offered this retention measure in Table 1.

As summarized in Table 1, the group of 61-year-olds being offered a retaining bonus consists of a somewhat higher share of women and the mean income percentile of this group is somewhat lower than for the group not being offered a retaining bonus. The descriptive statistics also show that the share working full-time 30 hours or more is 
Table I Descriptive statistics - control variables and a selection of key information for the group of 61 -year-olds being offered a retaining bonus and the 61 -year-olds not being offered this retention measure

\begin{tabular}{|c|c|c|}
\hline & Bonus & No bonus \\
\hline Women & 69.7 & 60.2 \\
\hline Men & 30.3 & 39.8 \\
\hline Elementary school & 19.18 & 20.02 \\
\hline High school & 45.67 & 43.59 \\
\hline Undergraduate from university/college & 28.43 & 26.94 \\
\hline Postgraduate from university/college & 6.72 & 9.45 \\
\hline Income percentile, mean (s.d.) & $43.93(28)$ & $50.72(29)$ \\
\hline Spouse income percentile, mean (s.d.) & $46.47(31)$ & $44.82(31)$ \\
\hline Household debts percentile, mean (s.d.) & $37.96(29)$ & $42.10(29)$ \\
\hline $\begin{array}{l}\text { Spouse retired on AFP } \\
\text { retirement scheme }\end{array}$ & 8.05 & 6.29 \\
\hline Spouse retired on disability pension & 15.55 & 15.62 \\
\hline Full-time 30 hours or more & 62.5 & 72.9 \\
\hline Part-time $20-29$ hours & 19.1 & 14.9 \\
\hline Part-time $<20$ hours & 18.4 & 12.2 \\
\hline Worker & 63.9 & 41.5 \\
\hline Routine nonmanual employee & 17.6 & 32.8 \\
\hline Professional, administrator, or official & 18.5 & 25.7 \\
\hline Public administration & 12.7 & 9.4 \\
\hline Other industries & 5.1 & 15.4 \\
\hline Teaching & 31.1 & 27.2 \\
\hline Health and social services & 34.1 & 26.0 \\
\hline Manufacturing & 8.3 & 9.7 \\
\hline Construction & 3.1 & 3.1 \\
\hline Hotels and restaurants & 0.04 & 3.9 \\
\hline Wholesale and retail trade & 5.6 & 5.3 \\
\hline N & 2680 & 9833 \\
\hline
\end{tabular}


somewhat lower for the group of 61-year-olds being offered a retaining bonus, whereas the distribution according to occupational class shows that the share of workers is somewhat higher. Among the 61-year-olds being offered a bonus, there is also a somewhat higher share of employees who work in public administration, teaching, and health and social services.

\section{RESULTS}

All analyses were performed using Stata, version 12, and all models presented in the four tables have been estimated using individual fixed effects and linear probability models. We present the results for all bonuses and bonuses of 20,000 NOK or more in Table 2. As summarized in the table, the overall probability of a 61-year-old withdrawing a contractual pension is $22 \%$ when turning 62 and $31 \%$ when turning 63 . When looking at the results for all bonuses, 61-year-olds being offered a bonus at age 62 do not have a lower probability of retiring in the next two years of employment. This result does not change when including the control variables in model 2.

However, when investigating the effect of bonuses with an offered amount of 20,000 NOK or more, 61-year-olds being offered the retaining bonus have a 5.7\% lower overall probability of retiring in the next two years of employment. The results also show that the probability of retiring early on the contractual pension is reduced with an increase in income percentile and spouse income percentile. Furthermore, having a spouse who

Table 2 Individual probability of withdrawing a contractual pension among 61 -year-olds in the next two years of employment, having been exposed to bonus as a retention measure from age 62 , all amounts and 20,000 NOK or more

\begin{tabular}{|c|c|c|c|c|}
\hline & $\begin{array}{l}\text { All bonuses } \\
\text { Model I }\end{array}$ & $\begin{array}{l}\text { All bonuses } \\
\text { Model } 2\end{array}$ & $\begin{array}{c}\text { Bonus } \geq \\
\text { 20,000 NOK } \\
\text { Model I }\end{array}$ & $\begin{array}{c}\text { Bonus } \geq \\
20,000 \text { NOK } \\
\text { Model } 2\end{array}$ \\
\hline Retention measure - bonus & -0.023 & -0.018 & $-0.065 * * *$ & -0.057 ***** \\
\hline Age 62 & 0.221 **** & $0.216 * * *$ & $0.220 * * * *$ & $0.215^{* * * *}$ \\
\hline Age 63 & $0.335 * * * *$ & $0.307 * * * *$ & $0.334 * * * *$ & $0.307 * * * *$ \\
\hline Income percentile & & $-0.005 * * * *$ & & $-0.005^{* * * * *}$ \\
\hline Spouse income percentile & & $-0.00 \mid * * * *$ & & $-0.00 \mid$ 米** \\
\hline Household debts percentile & & -0.000 & & -0.000 \\
\hline Spouse retired on contractual pension & & $0.110 * * * *$ & & 0.111 ***** \\
\hline Spouse retired on disability pension & & 0.021 & & 0.018 \\
\hline$R^{2}$ within-group & 0.254 & 0.285 & 0.259 & 0.282 \\
\hline Number of observations & 35,946 & 35,946 & 34,626 & 34,626 \\
\hline Number of groups & 12,513 & 12,513 & 12,513 & 12,513 \\
\hline
\end{tabular}

***: $p \leq 0.05$, ****: $p \leq 0.01$ 
Table 3 Individual probability of withdrawing a contractual pension among 61 -year-old women and men in the next two years of employment, having been exposed to bonus as a retention measure from age 62, according to gender, all amounts and 20,000 NOK or more

\begin{tabular}{|c|c|c|c|c|}
\hline & $\begin{array}{l}\text { Women } \\
\text { All bonuses }\end{array}$ & $\begin{array}{c}\text { Men } \\
\text { All bonuses }\end{array}$ & $\begin{array}{c}\text { Women } \\
\text { Bonus } \geq 20,000\end{array}$ & $\begin{array}{c}\text { Men } \\
\text { nus } \geq 20,000\end{array}$ \\
\hline & & & NOK & NOK \\
\hline Retention measure - bonus & -0.015 & -0.022 & $-0.036 * *$ & $-0.122 * * * *$ \\
\hline Age 62 & $0.207^{* * * * *}$ & $0.228^{* * * * *}$ & $0.205^{* * * * *}$ & $0.228^{* * * * *}$ \\
\hline Age 63 & $0.302 * * * *$ & 0.3||$* * * *$ & $0.303 * * * *$ & $0.310 * * * *$ \\
\hline Income percentile & -0.006 ***** & $-0.005 * * * * *$ & $-0.005 * * * *$ & $-0.005^{* * * * *}$ \\
\hline Spouse income percentile & $-0.00 \mid$ 米** & 0.000 & $-0.00 \mid$ 米** & 0.000 \\
\hline Household debts percentile & -0.000 & 0.000 & -0.000 & 0.000 \\
\hline Spouse retired on contractual pension & $0.086^{* * * * *}$ & $0.182^{* * * * *}$ & 0.086 **** & 0.191 米米 \\
\hline Spouse retired on disability pension & 0.002 & 0.057 & -0.001 & 0.055 \\
\hline$R^{2}$ within-group & 0.279 & 0.297 & 0.276 & 0.296 \\
\hline Number of observations & 22,396 & 13,542 & 21,610 & |3,008 \\
\hline Number of groups & 7785 & 4728 & 7785 & 4728 \\
\hline
\end{tabular}

***: $p \leq 0.05$, ****: $p \leq 0.01$

retires on the contractual pension significantly increases the probability of retiring early in the next two years of employment.

The results are divided according to gender in Table 3. The results show that neither women nor men being offered a retaining bonus, irrespective of the amount being offered, have a lower probability of retiring early. However, women being offered a bonus of $20,000 \mathrm{NOK}$ or more have on average a $3.6 \%$ lower probability of retiring early, whereas the effect for men is $12.2 \%$.

To further investigate the importance of the amount being offered, we have performed the analysis according to income group, dividing between the lowest third, the mid third, and the top third of the income distribution at age 61. Tables 4 and 5 present the results divided by gender, income group, and the amount being offered.

As summarized in Table 4, only women in the lowest third of the income distribution at age 61 have a significantly lower probability of retiring in the next two years of employment, on average $5.3 \%$, when offered a bonus of 20,000 NOK or more. The result for men is quite the opposite, as summarized in Table 5, only men in the top third of the income distribution at age 61 have a significantly lower probability of retiring in the next two years of employment when being offered a retaining bonus.

Men in the top third of the income distribution being offered a retaining bonus, irrespective of the amount being offered, have on average a $5.9 \%$ lower probability of retiring in the next two years of employment. Furthermore, those being offered a bonus of 20,000 NOK or more have on average a $14.6 \%$ lower probability of retiring early at the ages of 62 or 63 . 
Table 4 Individual probability of withdrawing a contractual pension among 61 -year-old women in the next two years of employment, having been exposed to bonus as a retention measure, according to income at age 61 , all amounts and 20,000 NOK or more

\begin{tabular}{|c|c|c|c|c|c|c|}
\hline & \multicolumn{2}{|c|}{$\begin{array}{l}\text { Women } \\
\text { The lowest third of the } \\
\text { income distribution at } \\
\text { age } 61\end{array}$} & \multicolumn{2}{|c|}{$\begin{array}{l}\text { Women } \\
\text { The mid third of the } \\
\text { income distribution at } \\
\text { age } 61\end{array}$} & \multicolumn{2}{|c|}{$\begin{array}{l}\text { Women } \\
\text { The top third of the } \\
\text { income distribution at } \\
\text { age 6I }\end{array}$} \\
\hline & $\begin{array}{c}\text { All } \\
\text { bonuses }\end{array}$ & $\begin{array}{c}\text { Bonus } \geq \\
20,000 \\
\text { NOK }\end{array}$ & $\begin{array}{c}\text { All } \\
\text { bonuses }\end{array}$ & $\begin{array}{c}\text { Bonus } \geq \\
20,000 \\
\text { NOK }\end{array}$ & $\begin{array}{c}\text { All } \\
\text { bonuses }\end{array}$ & $\begin{array}{c}\text { Bonus } \geq \\
20,000 \\
\text { NOK }\end{array}$ \\
\hline $\begin{array}{l}\text { Retention } \\
\text { measure - bonus }\end{array}$ & -0.033 & $-0.053^{*} *$ & -0.012 & -0.045 & -0.000 & 0.001 \\
\hline Age 62 & $0.234 * * *$ & $0.230 * * *$ & 0.201 ***** & $0.200 * * * *$ & $0.157^{* * * * *}$ & 0.155 **** \\
\hline Age 63 & $0.336 * * * *$ & 0.335 **** & $0.289 * * * *$ & 0.29 |***** & 0.237 ****** & 0.242 ****** \\
\hline Income percentile & -0.005 **** & $-0.005^{*} * * *$ & $-0.008 * * * *$ & $-0.007 * * * *$ & -0.006 ***** & $-0.006^{\text {******* }}$ \\
\hline $\begin{array}{l}\text { Spouse income } \\
\text { percentile }\end{array}$ & -0.00 I**** & $-\left.0.00\right|^{* * *}$ & $-0.002 * * * *$ & $-0.002 * * *$ & -.000 & -.000 \\
\hline $\begin{array}{l}\text { Household debts } \\
\text { percentile }\end{array}$ & -0.001 & -0.000 & -0.000 & -0.000 & -0.000 & -0.000 \\
\hline $\begin{array}{l}\text { Spouse retired } \\
\text { on contractual } \\
\text { pension }\end{array}$ & 0.089 ***** & 0.087 ***** & $0.068 * * * *$ & $0.070 * * * *$ & $0.102 * *$ & $0.098^{*} *$ \\
\hline $\begin{array}{l}\text { Spouse retired on } \\
\text { disability pension }\end{array}$ & 0.012 & 0.008 & 0.008 & 0.014 & -0.030 & -0.062 \\
\hline $\mathrm{R}^{2}$ within-group & 0.275 & 0.272 & 0.303 & 0.299 & 0.269 & 0.268 \\
\hline $\begin{array}{l}\text { Number of obser- } \\
\text { vations }\end{array}$ & $|0,33|$ & 9980 & 7525 & 7235 & 4540 & 4395 \\
\hline Number of groups & 3527 & 3527 & 2616 & 2616 & 1576 & 1576 \\
\hline
\end{tabular}

***: $p \leq 0.05, * * * *: p \leq 0.01$

Table 5 Individual probability of withdrawing a contractual pension among 61 -year-old men in the next two years of employment, having been exposed to bonus as a retention measure, according to income at age 6I, all amounts and 20,000 NOK or more

\begin{tabular}{|c|c|c|c|c|c|c|}
\hline & \multicolumn{2}{|c|}{$\begin{array}{l}\text { Men } \\
\text { The lowest third of the } \\
\text { income distribution at } \\
\text { age } 61\end{array}$} & \multicolumn{2}{|c|}{$\begin{array}{l}\text { Men } \\
\text { The mid third of the } \\
\text { income distribution at } \\
\text { age } 61\end{array}$} & \multicolumn{2}{|c|}{$\begin{array}{l}\text { Men } \\
\text { The top third of the } \\
\text { income distribution at } \\
\text { age 6I }\end{array}$} \\
\hline & All bonuses & $\begin{array}{c}\text { Bonus } \geq \\
20,000 \\
\text { NOK }\end{array}$ & All bonuses & $\begin{array}{c}\text { Bonus } \geq \\
20,000 \\
\text { NOK }\end{array}$ & All bonuses & $\begin{array}{c}\text { Bonus } \geq \\
20,000 \\
\text { NOK }\end{array}$ \\
\hline $\begin{array}{l}\text { Retention } \\
\text { measure - bonus }\end{array}$ & -0.043 & -0.113 & 0.049 & -0.069 & $-0.059 * *$ & $-0.146 * * * *$ \\
\hline
\end{tabular}




\begin{tabular}{|c|c|c|c|c|c|c|}
\hline & \multicolumn{2}{|c|}{$\begin{array}{l}\text { Men } \\
\text { The lowest third of the } \\
\text { income distribution at } \\
\text { age 6I }\end{array}$} & \multicolumn{2}{|c|}{$\begin{array}{c}\text { Men } \\
\text { The mid third of the } \\
\text { income distribution at } \\
\text { age } 61\end{array}$} & \multicolumn{2}{|c|}{$\begin{array}{l}\text { Men } \\
\text { The top third of the } \\
\text { income distribution at } \\
\text { age } 6 \mathrm{I}\end{array}$} \\
\hline & All bonuses & $\begin{array}{c}\text { Bonus } \geq \\
20,000 \\
\text { NOK }\end{array}$ & All bonuses & $\begin{array}{c}\text { Bonus } \geq \\
20,000 \\
\text { NOK }\end{array}$ & All bonuses & $\begin{array}{c}\text { Bonus } \geq \\
20,000 \\
\text { NOK }\end{array}$ \\
\hline Age 62 & 0.231 ***** & $0.222 * * * *$ & $0.28 I^{* * * * * *}$ & $0.282 * * * *$ & $0.186 * * *$ & $0.188 * * * *$ \\
\hline Age 63 & $0.318 * * *$ & $0.312 * * * *$ & 0.362 ***** & $0.366 * * *$ & $0.260 * * *$ & 0.258 **** \\
\hline $\begin{array}{l}\text { Income per- } \\
\text { centile }\end{array}$ & $-0.002 * * * *$ & $-0.002 * * *$ & $-0.005^{* * * *}$ & $-0.005 * * * *$ & $-0.006 * * * *$ & -0.006 ***** \\
\hline $\begin{array}{l}\text { Spouse income } \\
\text { percentile }\end{array}$ & 0.003 & $0.004 * *$ & -0.000 & -0.002 & 0.000 & 0.000 \\
\hline $\begin{array}{l}\text { Household debts } \\
\text { percentile }\end{array}$ & -0.002 & -0.002 & 0.001 & 0.001 & -0.000 & -0.000 \\
\hline $\begin{array}{l}\text { Spouse retired } \\
\text { on contractual } \\
\text { pension }\end{array}$ & -0.023 & -0.024 & $0.270 * * * *$ & $0.290 * * * *$ & $0.158 * * *$ & $0.166 * * * *$ \\
\hline $\begin{array}{l}\text { Spouse retired } \\
\text { on disability } \\
\text { pension }\end{array}$ & 0.012 & 0.010 & $0.116 * *$ & $0.137 * * * *$ & 0.009 & -0.010 \\
\hline$R^{2}$ within-group & 0.250 & 0.247 & 0.350 & 0.347 & 0.289 & 0.289 \\
\hline $\begin{array}{l}\text { Number of } \\
\text { observations }\end{array}$ & 1608 & 1540 & 4511 & 4330 & 7423 & 7138 \\
\hline $\begin{array}{l}\text { Number of } \\
\text { groups }\end{array}$ & 567 & 567 & 1580 & 1580 & 2584 & 2584 \\
\hline
\end{tabular}

***: $p \leq 0.05$, ****: $p \leq 0.0$ I

\section{DISCUSSION}

This paper revisits a long-debated subject in early retirement research, namely the importance of financial incentives in the transition between work and retirement. Financial considerations and constraints do undoubtedly affect the opportunity structure of older workers in the transition between work and retirement and there is, as previously highlighted, a substantial strand of research showing that financial incentives have a significant impact on retirement behavior (Bratsberg et al., 2008; Gruber \& Wise, 2010; $\mathrm{Radl}, 2012$ ). However, research also indicates that the financial reward must be of a significant size to alter an early-exit decision (Hernæs, 1999; Krueger \& Pischke, 1992).

Unlike these previous studies investigating the effect of 'passive' policies at the national level, our analysis is based on investigating the effects of an 'active' measure at the company level - offering a modest lump sum of money to prevent older workers from making an early exit. To our knowledge, this is the first study investigating the effect of retaining bonuses on early retirement behavior. Thus, we address a gap in the literature on the 
significance of financial incentives for early retirement behavior. Our results show that a retaining bonus of $20,000 \mathrm{NOK}$ or more (equal to $54 \%$ of a mean monthly income in 2010) does reduce the probability of retiring early; however, it should be emphasized that the mean reduction is only $5.7 \%$.

Inspired by Larsen (2008), we went further than investigating the overall effect of the retaining bonus, performing separate analyses for women and men. As previously mentioned, Larsen found that the retirement plans of male workers are more affected by an increase in earnings than those of female workers, suggesting that employerinitiated efforts to retain older workers will not necessarily be as effective for female as for male workers. Our analysis supports this hypothesis, when separating between men and women, our results show that women being offered a bonus of 20,000 NOK or more have on average $3.6 \%$ lower probability of retiring early, whereas the effect for men was $12.2 \%$. These results suggest that the retaining bonus is a more effective measure when targeting men than when targeting women.

The retaining bonus, investigated in this paper, is essentially a purely financial incentive, as it does not involve any adaptation of the work situation or strengthening of employees' work ability (Hermansen \& Midtsundstad, 2015). Thus, as previously argued, the retaining bonus will mainly reduce the significance of economic 'pull factors' in the transition between work and retirement, as it changes the compensation rate, making work more economically valuable than leisure. Nevertheless, being offered a retaining bonus arguably also sends a signal to older workers that they are wanted and appreciated by the company, irrespective of the pure financial value it may represent for the employees. Such signals may help to reduce the significance of culturally constructed beliefs about when older workers should leave the labor market.

This 'signal effect' embedded in the retaining bonus may be as important for older employees as the financial effect of the bonus when they are weighing the pros and cons of continuing working versus leaving the labor market altogether. However, analysis based on register data provides at best only indirect insight into the complexity of desires, believes, and opportunities faced by older workers in the transition between work and retirement. Thus, given the data we use in our analyses, we are unable to distinguish between the relative significance of these two factors. Nevertheless, the financial incentive embedded in the retaining bonus will arguably be greater for those in the lower income groups, given that the sum offered will constitute a larger percentage of income for lower income groups than for higher income groups. Thus, one might argue that for those with low income, the retaining bonus may both act as a signal and as a financial incentive, whereas for those with higher wages, the bonus primarily acts as signal, given the low sum being offered.

To further investigate the significance of retaining bonuses in the transition between work and retirement, we performed separate analysis according to income group, separating between women and men and according to the amount being offered. The results show that for women, only those in the lowest third of the income distribution at age 61 have a lower probability of retiring early when being offered a bonus of 20,000 NOK or more. For men, by contrast, only those in the highest third of the income distribution at age 61 have a lower probability of retiring early. The results show that men with the highest earnings have on average $5.9 \%$ lower probability of retiring early when being offered a bonus, irrespective of the sum being offered. When delimiting the analysis to retaining bonuses of 20,000 NOK or more, men with the highest earnings being offered this measure have on average $14.6 \%$ lower probability of making an early exit in the next two years of employment. 
Given these results, it seems reasonable to assume that older women in the lowest income group are retained primarily by the financial incentive embedded in the retaining bonus. This argument is supported by the fact that we find no effect of the bonus when investigating all bonuses, irrespective of the amount being offered. The results show that only bonuses of 20,000 NOK or more have an effect on the early retirement probability for older women with the lowest earnings. Whereas, for older men in the highest third of the income distribution, the results indicate that both the 'signal effect' and the financial incentive embedded in the retaining bonus might be of importance when they are weighing the pros and cons of continuing working versus leaving the labor market altogether.

Radl (2013) underscores that the opportunity structure of older workers is to a significant degree shaped by their health and financial situation. Radl argues that only those who are healthy and have a job, or the chance of getting one, can opt for continued work, and only those who have accumulated the necessary pension entitlements or who hold significant assets can afford to retire early. Given these facts, we must emphasize that the data used in our analyses consisted exclusively of older employees who were all working at the age of 61 . These employees can be assumed to be healthier than the population of older employees as a whole, since a large proportion of Norwegian employees leave the labor market on the disability pension before they turn 60 (Midtsundstad et al., 2012). Thus, our results cannot be generalized outside the age group investigated in this paper and we cannot rule out the possibility that the effect of the retaining bonus presupposes a target group which constitutes a relatively healthy group of older workers.

Furthermore, the financial situation is undoubtedly a key element in the opportunity structure facing older workers and financial constraints vary significantly between different income groups (Radl, 2012). Moreover, it seems reasonable to assume that older male workers in the top third of the income distribution have accumulated the necessary pension entitlements and have the assets making early retirement an affordable option. Thus, this group of older workers may have a desire to keep on working, they believe they are able to keep up and their health provides them with the opportunity to do so; being offered a bonus may just be the triggering mechanism for them to stay on.

For older women in the lowest third of the income distribution, however, early retirement may be desirable, especially if they have health problems, but low pension entitlements and a lack of assets, due to shorter careers and more part time work, may force them to continue working. Men in the lowest third of the income distribution will, on the other hand, due to longer careers and full time work, to a larger degree have accumulated the necessary pension entitlement to follow they desire to retire, if they have health problems. In other words, the effect of the retaining bonus may not only be conditioned by level of income but also by the employee's pension entitlements and assets.

For older men in the top third of the income distribution, the retaining bonus not only marginally increases the benefits of continuing working but also motivates them to keep on working for a few more years. For women in the lowest third of the income distribution, on the other hand, low pension entitlements, a lack of assets, and being offered a retaining bonus of 20,000 NOK or more makes continuing working a financial necessity, rather than a motivated choice. 


\section{CONCLUSION}

In this paper, we have analyzed the effect of the retaining bonus on early retirement behavior using a unique dataset consisting of a Norwegian employer survey from 2010 combined with register data on all older employees in the period 2000-2010. In spite of the relatively low sum being offered to prevent older workers from making an early exit, our analysis shows that retaining bonuses of $20,000 \mathrm{NOK}$ or more (equal to $54 \%$ of a mean monthly income in 2010) do reduce the probability of 61-year-olds retiring in the next two years of employment. However, it needs to be emphasized that the probability of 61 -year-olds retiring in the next two years is only reduced with $5.7 \%$ on mean. This just illustrates the fact that the early retirement puzzle is complex and being offered a retaining bonus is just one of many factors in the work-retirement transition.

When separating according to income group, our results indicate that both the financial incentive and the 'signal effect' embedded in the retaining bonus affect the retirement decision of older men in the top third of the income distribution. For women on the other hand, the effect of the retaining bonus for those in the lowest third of the income distribution seems to derive from the increased financial gains of working a few more years.

As previously mentioned, register data provide at best only indirect insight into the desires, believes, and opportunities facing older workers. Thus, we are unable to fully grasp this complexity in the present study, and interpretation of the results must inevitably be based on assumptions and indirect evidence. Nevertheless, older workers still working at the age of 61 is arguably a select group of employees. Therefore, the results presented in this paper only provide insight into the effect of one single measure used to retain older workers, in a defined period of time, and for a select group of employees.

One can also question, as Midtsundstad and Bogen (2011) have, whether the use of standardized retention measures or a one-size-fits-all approach, such as offering a retaining bonus, is the most appropriate way to retain older workers given the heterogeneity of needs, problems, and challenges facing different industries and groups of older employees. Furthermore, employees are only eligible for these measures at the age of 62, which in many sectors and industries is too high to make a difference for individuals at the risk of becoming disabled. As Midtsundstad and Bogen (2011) argue, retaining efforts, including bonuses, may prove to be more effective if targeted according to the heterogeneity of needs, problems, and challenges facing different industries and groups of employees.

As an alternative to the emphasis on incentives, Midtsundstad (2015) argues for the importance of a broader approach to active aging in Norway, in which the prevention of health problems and reduced work capacity is more emphasized. A broader focus to active aging will potentially enhance the opportunity structure of the less healthy and work-able older workers. Along similar lines, Larsen (2008) argues for improving older workers' quality of work as a strategy for reversing the tendency toward early withdrawal from the labor market. Reducing health impairment, by improving working conditions and focusing on early prevention, may not only provide older workers with the opportunity to continue working, but also be an incentive to continue working by enhancing the desire to work longer and the belief in one's ability to do so (Larsen, 2008; Midtsundstad, 2015). Instead of offering a retaining bonus, which is essentially 
just an incentive, not affecting the work situation or work ability of older workers, one might argue, as Paullin and Whetzel (2012) have, that the easiest and least costly retention strategy may be just to simply ask healthy and work-able older workers to continue working and strive to make them feel valued.

\section{Acknowledgments}

This work was supported by The Research Council of Norway as part of the project 'Senior Policy for Whom? The Distributional Consequences and Effects of Initiatives to Promote Active Ageing grant number 218364'.

\section{References}

Angrist, J.D. \& Pischke, J.S. (2008). Mostly harmless econometrics: An empiricist's companion. Princeton University Press, Princeton.

Becken, L.E. (2011). Redusert arbeidstid med full lønnskompensasjon blant seniorer med rett til AFP i fire statlige etater [Reduced working hours with full wage compensation among seniors eligible to retire early in four state agencies]. Søkelys på arbeidslivet, 28(4), 374 -393.

Bratsberg, B., Røed, K. and Raaum, O. (2008). Må arbeid lønne seg i et inkluderende arbeidsliv? [Must work pay off in an inclusive labor market?] Tidsskrift for Velferdsforskning, 11(1), 49-61.

Brown, C. (2002). Early retirement windows. Working Paper 2002-028. Ann Arbor, MI: Michigan Retirement Research Center University of Michigan. doi: https://doi. org/10.2139/ssrn.1596115.

Calvo, E., Sarkisian, N. \& Tamborini, C.R. (2013). Causal Effects of Retirement Timing on Subjective Physical and Emotional Health. The Journals of Gerontology Series B: Psychological Sciences and Social Sciences, 68 (1), 73-84. doi: https://doi.org/10.1093/ geronb/gbs097.

Corsi, M. \& Samek, M.L. (2010). Active ageing and gender equality policies: The employment and social inclusion of women and men of late working and early retirement age. EGGSI Report for the European Commission, Brussels.

da Silva Soca, M.L. (2013). Tax Incentives to Promote Active Ageing: The Introduction of the Doorwerkbonus in the Netherlands. Tilburg: Tilburg University.

de Vroom, B. (2004). Age-arrangements, age-culture and social citizenship: A conceptual framework for an institutional and social analysis. In T. Maltby, B. de Vroom, M. L. Mirabile \& E. Øverbye (Eds.), Ageing and the Transition to Retirement: A Comparative Analysis of European Welfare State (pp. 6-17). Aldershot: Ashgate.

Doherty, M. (2009). When the working day is through: the end of work as identity? Work, Employment \& Society, 23, 1, 84-101. doi: https://doi.org/10.1177/0950017008099779.

Engelhardt, H. (2012). Late Careers in Europe: Effects of Individual and Institutional Factors. European Sociological Review, 28 (4), 550-563. doi: 10.1093/esr/jcr024

Esser, I. (2005). Continued Work or Retirement? Preferred Exit-age in Western European countries. Stockholm: Institute for Future Studies.

Gruber, J. \& Wise, D.A. (2010). Social Security Programs and Retirement around the World: The Relationship to Youth Employment. Chicago: University of Chicago Press. doi: http://doi.org/10.7208/chicago/9780226309507.001.0001.

Gørtz, M. (2012). Early retirement in the day-care sector: the role of working conditions and health. European Journal of Ageing, 9 (3), 187-198. 
Hallberg, D. \& Eklöf, M. (2010). Do buy-outs of older workers matter?: Estimating retirement behavior with special early retirement offers. International Journal of Manpower, 31 (3), 337-359. doi: https://doi.org/10.1108/01437721011050611.

Halvorsen, K. (1977). Arbeid eller trygd? [Work or Social Security?] Pax, Oslo.

Henkens, K., \& van Dalen, H. P. (2012). The employer's perspective on retirement. In M. Wang (Ed.), The Oxford handbook of retirement (pp. 215-228). New York: Oxford University Press.

Hermansen, A. (2014). Additional Leave as the Determinant of Retirement Timing-Retaining Older Workers in Norway. Nordic journal of working life studies, 4 (4), 89-108. doi: http://dx.doi.org/10.19154/njwls.v4i4.4709.

Hermansen, Å. (2015). Retaining older workers: The effect of phased retirement on delaying early retirement. Nordic Journal of Social Research (6), 44 - 67. doi: http://dx.doi. org/10.15845/njsr.v6i0.601.

Hermansen, Å. \& Midtsundstad, T. (2015). Retaining older workers-analysis of company surveys from 2005 and 2010. International Journal of Manpower, 36 (8), 1227-1247. doi: http://dx.doi.org/10.1108/IJM-07-2014-0150.

Hernæs, E., Sollie, M. \& Strøm, S. (2000). Early retirement and economic incentives. The Scandinavian Journal of Economics, 102 (3), 481-502.

Hernæs, E., Røed, K. \& Strøm, S. (2002). Yrkesdeltakelse, pensjoneringsadferd og økonomiske insentiver. [Labour force participation, retirement behavior and economic incentives]. Oslo: Frischsenteret.

Hilsen, A.I. \& Midtsundstad, T. (2014). Seniorpolitikk—behov for nytt kart og kompass? [Senior policy- in needed of a new map and compass?] Søkelys på arbeidslivet (1-2), 157-182.

Hilsen, A.I. \& Midtsundstad, T. (2015). Domain: Human resource management and interventions. In Hasselhorn, H.M. \& Apt, W. (Eds.), Understanding employment participation of older workers: Creating a knowledge base for future labour market challenges. BMAS/BAuA, Berlin.

Jensen, P.H. (2011), Arbejdsgivernes fastholdelsesstrategier set fra et lønmodtagersynspunkt. [Employers retaining strategies seen from the employee's point of veiw] I J. Goul Andersen \& P. H. Jensen (red.). Tilbagetrcekning fra arbejdsmarkedet: àrsager og effekter (S. 79-94). Frederiksberg: Frydenlund Academic, 2011.

Jensen, P.H. \& Øverbye, E. (2013). The work-retirement puzzle. In Jensen, P.H. \& Øverbye (Eds.), Down and out - or free at last? Berlin: Logos Verlag.

Kooij, D.T., De Lange, A.H., Jansen, P.G., Kanfer, R. \& Dikkers, J.S. (2011). Age and work-related motives: Results of a meta-analysis. Journal of Organizational Behavior, 32 (2), 197-225. doi: https://doi.org/10.1002/job.665.

Kooij, D.T., Guest, D.E., Clinton, M., Knight, T., Jansen, P.G. \& Dikkers, J.S. (2013). How the impact of HR practices on employee well-being and performance changes with age. $\mathrm{Hu}$ man Resource Management Journal, 23 (1), 18-35. doi: https://doi.org/10.1111/17488583.12000.

Krueger, A. B. \& Pischke, J.S. (1992). The effect of social security on labour supply: A cohort analysis of the notch generation. Journal of Labour Economics, 10 (4), 412-437.

Larsen, M. (2004). Retaining Older Workers in the Danish labour market. PhD thesis. Departement of Economics. Aarhus School of Business, Aarhus.

Larsen, M. (2008). Does quality of work life affect men and women's retirement planning differently? Applied Research in Quality of Life, 3(1), 23-42.

Lancee, B. \& Radl, J. (2012). Social connectedness and the transition from work to retirement. The Journals of Gerontology Series B: Psychological Sciences and Social Sciences, 67 (4), 481-490. doi: https://doi.org/10.1093/geronb/gbs049. 
Lien, O.C. (2013). Få bytter jobb etter fylte 50 år. [Few change jobs after the age of 50.] Arbeid og velferd, (1), 37-50.

Midtsundstad, T. (2005). Ikke nødvendigvis sliten... En analyse av tidligpensjonering og seniorpolitikk i staten. [Not necessarily tired ... An analysis of public sector AFP retirement.] Oslo:Forskningsstiftelsen Fafo.

Midtsundstad, T. (2015). IA som strategi for lengre yrkeskarrierer - En analyse av virksombetenes seniorpolitikk og dens effekt på tidligpensjoneringen. [IWL as a strategy for longer working careers - An analysis of the company's senior policy and its effect on early retirement.] PhD-avhandling Oslo: Universitetet i Oslo.

Midtsundstad, T. \& Bogen, H. (2011). Ulikt arbeid - ulike behov: seniorpolitisk praksis $i$ norsk arbeidsliv. [Different work-Different needs: Senior policy in Norway.] Oslo:Forskningsstiftelsen Fafo.

Midtsundstad, T., Hermansen, Å. \& Nielsen, R.A. (2012). Effects of Companies’ Initiatives to Reduce Early Retirement Among Older Workers. Nordic Journal of Working Life Studies, 2, 3, pp. 89-108. doi: http://dx.doi.org/10.19154/njwls.v2i3.2365.

Midtsundstad, T.I. (2011). Inclusive workplaces and older employees: an analysis of companies' investment in retaining senior workers. The International Journal of Human Resource Management, 22 (06), 1277-1293. doi: http://dx.doi.org/10.1080/09585192.2011.559099.

LO \& NHO (2017). Evaluering av AFP i privat sektor. Rapport fra arbeidet. [Evaluation of the AFP-scheme in the private sector. A report from the evaluation] 7. desember 2017. Oslo: LO \& NHO.

Nergaard, K. (2009). Hvem har ikke AFP? En analyse med basis i registerbaserte data. [Who do not have a contractual pension? An analysis based on administrative data.] Oslo:Forskningsstiftelsen Fafo.

OECD. (2006). Live longer, work longer. Paris: Organization for Economic Cooperation and Development. doi: https://doi.org/10.1787/9789264035881-en.

OECD. (2013). Ageing and Employment Policies: Norway 2013 Working Better with Age. Paris: Organization for Economic Cooperation and Development.

Paullin, C., \& Whetzel, D. L. (2012). Retention strategies and older workers. In W. C. Borman \& J. W. Hedge (Eds.), The Oxford Handbook of Work and Aging. (pp.: 392-418). Oxford: Oxford University Press.

Phillipson, C. (2013). Commentary: The future of work and retirement. Human relations, 66 (1), 143-153. doi: https://doi.org/10.1177/0018726712465453.

Radl, J. (2012). Too old to work, or too young to retire? The pervasiveness of age norms in Western Europe. Work, Employment \& Society, 26 (5), 755-771. doi: https://doi. org/10.1177/0950017012451644.

Radl, J. (2013). Labour market exit and social stratification in Western Europe: The effects of social class and gender on the timing of retirement. European Sociological Review, 29 (3), 654-668. doi: https://doi.org/10.1093/esr/jcs045.

Riach, K. \& Loretto, W. (2009). Identity work and the 'unemployed' worker: age, disability and the lived experience of the older unemployed. Work, Employment \& Society, 23 (1), 102-119. doi: https://doi.org/10.1177/0950017008099780.

Svalund, J., Saloniemi, A. \& Vulkan, P. (2016). Attitudes towards job protection legislation: Comparing insiders and outsiders in Finland, Norway and Sweden. European Journal of Industrial Relations, 1-20. doi: https://doi.org/10.1177/0959680115626057.

Vickerstaff, S., Cox, J. \& Keen, L. (2003). Employers and the management of retirement. Social Policy \& Administration, 37 (3), 271-287. doi: https://doi.org/10.1111/1467-9515.00338

Walker, A. \& Foster, L. (2013). Active ageing: Rhetoric, theory and practice. In Ervik, R. \& Skogedal Lindén, T. (Eds.), The Making of Ageing Policy: Theory and Practice in Europe. Edward Elgar Publishing Limited, Cheltenham. doi: https://doi.org/10.4337/978178195 2481.00009 . 
Walker, A. \& Maltby, T. (2012). Active ageing: a strategic policy solution to demographic ageing in the European Union. International Journal of Social Welfare, 21 (1), 117-130. doi: https://doi.org/10.1111/j.1468-2397.2012.00871.x.

Wooldridge, J.M. (2005). Fixed-effects and related estimators for correlated randomcoefficient and treatment-effect panel data models. Review of Economics and Statistics, 87 (2), 385-390. doi: https://doi.org/10.1162/0034653053970320.

Wooldridge, J.M. (2009). Introductory econometrics: A modern approach. Thomson/ South-Western, Mason, $\mathrm{OH}$.

\section{Notes}

1 According to Statistics Norway, the mean monthly pay before tax in 2010 was 36,700 Norwegian Kroner.

2 This entitlement age applied to $92(8 \%)$ of the 61-year-olds working in companies offering retaining bonuses in 2010 .

3 This level of compensation was available to $90(5 \%)$ of the 61-year-olds working in companies using bonuses as retention measures.

4 There are however some exceptions to this general rule, which affect, for example, employees in occupations with a special age limit and employees in companies with a defined contribution pension scheme, which consequently terminate employment contracts before the age of 70 , typically at the age of 67.

5 The respondents were asked when they expected/were planning to retire. 